Kalpa Publications in Civil Engineering
Volume 1, 2017, Pages 495-501
$\begin{gathered}\text { ICRISET2017. International Conference on Re- } \\ \text { search and Innovations in Science, Engineering } \\ \text { \&Technology. Selected papers in Civil Engineering }\end{gathered}$

\title{
Correlation Between Particle Fines and Laboratory CBR from Heavy Compaction Characteristics
}

\author{
Rima C. Dave ${ }^{1 *}$, Prof. Priti J. Mehta ${ }^{2 \dagger}$, Prof. Ketan L.Timani ${ }^{3}$ \\ ${ }^{1,2}$ L.D.College of Engineering Ahmedabad, Gujarat, \\ ${ }^{3}$ Vishwakarma Govt.Engg.College, Ahmedabad, Gujarat \\ rcdave12@gmail.com, mehta.priti67@gmail.com, ketantimani@yahoo.com
}

\begin{abstract}
The sub grade is a layer of natural soil, prepared to receive the layers of pavement. The thickness of pavement depends upon the properties of sub grade. Sub grade should be strong enough to take up the stresses imposed due to loads with out shear failure and excessive deformation. Sub grade soil strength is evaluated in terms of California Bearing Ratio and is used for design of flexible pavement. It can be performed both in the laboratory and field. The CBR test is laborious and time consuming, even though use of CBR as a performance parameter is widely acknowledged. Also it is very difficult to prepare sample at desired in situ density for laboratory testing. The CBR value depends on factors like particle fines, plasticity index, maximum dry density and optimum moisture content. The fine particles have engineering defect and its CBR value is low. This paper presents the effect of fine particles on CBR value. For the laboratory investigation, specimens were fabricated at optimum moisture content and maximum dry density by heavy compaction with varying proportion of sand, silt-clay and fine gravel mixtures. The samples were soaked in water for four days to simulate highly unfavorable condition. Correlation coefficient between fine particles and laboratory CBR values are obtained. Various linear relationships between index properties and CBR of the samples are investigated using linear regression analysis. Analysis of the experimental data indicated that there exist a good correlation among the measured value and predicted value of CBR
\end{abstract}

"PG student, Applied Mechanics

${ }^{\dagger}$ Associate Professor, Applied Mechanics Department, Associate Professor, Applied Mechanics Department

C.D. Modhera, G.J. Joshi, D. Soni, I.N. Patel, A.K. Verma, L.B. Zala, S.D. Dhiman, D.R. Bhatt, J.M. Rathod, B.C. Goradiya, M.S. Holia and D.K. Patel (eds.), ICRISET2017 (Kalpa Publications in Civil Engineering, vol. 1), pp. 495-501 


\section{Introduction}

The performance of pavement depends to a large extent on strength of sub grade material. The sub grade is the in-situ material on which pavement layers are placed. The sub grade performance generally depends on the load bearing capacity and volume change characteristics of the soil mass. Soil type, gradation, moisture, degree of compaction and presence of particle fines affect the load bearing capacity of soil. In pavement construction, entirely cohesive or non-cohesive materials are not used. The particle inter locking is modified due to presence of fine particles. Soils with excessive fines may be susceptible to shrink and swell depending upon their mineralogical content. California Bearing Ratio is the basic sub grade strength characterization accepted as a performance parameter all over the world. CBR is expressed as the percentage ratio of unit load $\mathrm{P}$ that has to be applied so that a standard circular piston may be pressed in to soil sample at a rate of $1.25 \mathrm{~mm} / \mathrm{min}$. and standard load. The sub base / base thickness is governed by the CBR value of sub grade.

\section{Materials Used}

2.1. Fine Grained Soil: The ingredient necessary to give soil deposit cohesion are clay minerals. There exists a reasonable relation between the type of mineral and activity of clayey soil. In the present investigation, clayey soil was collected at a depth of 0.3 to 0.5 foot from natural ground level from BHAL region. The various physical properties of the soil was evaluated as per the relevant IS standards. Based on the liquid limit and plasticity index, soil was classified as $\mathrm{CH}$ type.

Table1. Physical Properties of Clay Sample

\begin{tabular}{|c|c|c|c|c|c|}
\hline Sr. No. & Test & $\begin{array}{c}\text { Result } \\
\text { Obtained }\end{array}$ & Sr. No. & Test & $\begin{array}{c}\text { Result } \\
\text { Obtained }\end{array}$ \\
\hline 1 & $\begin{array}{l}\text { Specific } \\
\text { gravity }\end{array}$ & 2.76 & 8 & $\begin{array}{c}\text { Optimum } \\
\text { Moisture } \\
\text { Content (\%) }\end{array}$ & 18 \\
\hline 2 & Sand (\%) & 11 & 9 & $\begin{array}{l}\text { Maximum } \\
\text { dry density } \\
\left(\mathrm{kN} / \mathrm{m}^{3}\right)\end{array}$ & 17.1 \\
\hline 3 & Silt + clay $(\%)$ & 89 & 10 & $\begin{array}{l}\text { Cohesion } \\
\left(\mathrm{kg} / \mathrm{cm}^{2}\right)\end{array}$ & 1.42 \\
\hline 4 & $\begin{array}{l}\text { Liquid limit( } \\
\%)\end{array}$ & 54 & 11 & $\begin{array}{c}\text { Angle of } \\
\text { friction }\left(\emptyset^{\circ}\right)\end{array}$ & 10 \\
\hline 5 & $\begin{array}{c}\text { Plastic limit ( } \\
\%)\end{array}$ & 27 & 12 & $\begin{array}{l}\text { CBR (\%) -Un } \\
\text { soaked } \\
\text { condition } \\
\end{array}$ & 4.2 \\
\hline 6 & $\begin{array}{l}\text { Plasticity } \\
\text { Index }\end{array}$ & 27 & 13 & $\begin{array}{c}\text { CBR (\%) - } \\
\text { Soaked } \\
\text { condition }\end{array}$ & 1.8 \\
\hline 7 & $\begin{array}{c}\text { Free swell } \\
\text { index (\%) }\end{array}$ & 40 & & & \\
\hline
\end{tabular}


2.2. Coarse Grained Soil: The sand and gravel used in the present investigation is collected from Sabarmati river basin. Sand passing through $2 \mathrm{~mm}$ and retained on $0.425 \mathrm{~mm}$ and fine gravel of size $10 \mathrm{~mm}$ to $4.75 \mathrm{~mm}$ was used in the analysis. The co-efficient of uniformity is 1.66 and co-efficient of curvature is 1.06 for sand material, which indicates poor gradation and is classified as SP-SM. The co-efficient of uniformity is 1.27 and co-efficient of curvature is 0.90 for fine gravel. It is difficult to measure the shape than the size, the shape is not given required attention. As the material grading changes from a well graded to uniformly graded, the influence of shape is reduced.

\section{Methodology}

\subsection{Heavy Compaction Test (Modified Proctor Test)}

Modified proctor test were conducted on the different soil mixtures. The fine particles percentage by weight was varied for determination of optimum moisture content and maximum dry density. The proctor mould was compacted in five layers giving 25 blows to each layer by using modified rammer. Table II gives the results of modified proctor test.

\subsection{California Bearing Ratio Test}

In order to analyse the effect of particle fines and compaction characteristics on CBR as per IS 2720 (Part-16). The CBR values obtained for various percentage of clay under un soaked and soaked conditions are presented in Table II.

Table II. Summary of Modified Proctor Test and CBR Test Results

\begin{tabular}{|c|c|c|c|c|c|c|c|}
\hline $\begin{array}{l}\text { Sr. } \\
\text { No. }\end{array}$ & Clay (\%) & Sand (\%) & Gravel (\%) & $O M C(\%)$ & $M D D\left(k N / m^{3}\right)$ & $\underset{(\%)}{C B R}$ Unsoaked & CBR Soaked (\%) \\
\hline 1 & 10 & 45 & 45 & 8.26 & 21.49 & 74.98 & 60.50 \\
\hline 2 & 15 & 42.5 & 42.5 & 8.56 & 21.30 & 50.55 & 44.13 \\
\hline 3 & 20 & 40 & 40 & 9.10 & 21.00 & 42.06 & 36.85 \\
\hline 4 & 25 & 37.5 & 37.5 & 9.46 & 20.90 & 31.18 & 24.20 \\
\hline 5 & 30 & 35 & 35 & 9.90 & 20.81 & 23.55 & 15.60 \\
\hline 6 & 40 & 30 & 30 & $\begin{array}{ll} & 10.7 \\
5 & \end{array}$ & 20.50 & 16.75 & 11.28 \\
\hline 7 & 50 & 25 & 25 & $\begin{array}{ll} & 11.7 \\
0 & \end{array}$ & 20.10 & 13.08 & 8.32 \\
\hline
\end{tabular}

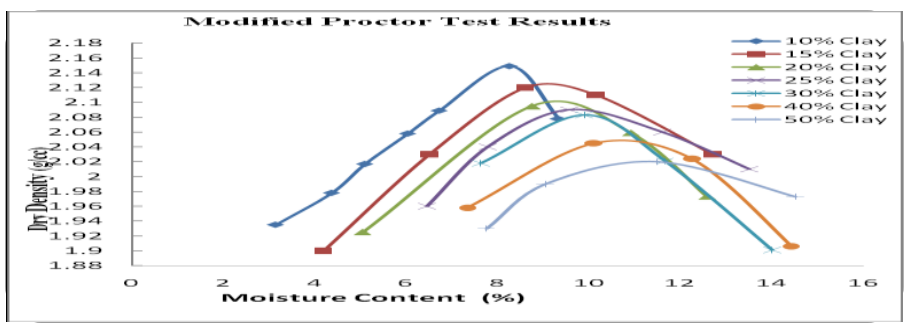

Fig. 1 Dry density Vs moisture content relation ship 


\section{Statistical Analysis of the Test Results}

Correlation matrix of various attributes is displayed in table IV. Simple linear regression analysis is applied to predict the value of un socked CBR and socked CBR using MDD and OMC as independent variable. Good results in terms of $R^{2}$ is obtained.. $R^{2}$ is the percentage of the response variable variation that is explained by a linear model. The higher values of $\mathrm{R}^{2}$ shows that the model fits best in both the cases.

TABLE III CORRELATION MATRIX OF VARIOUS ATTRIBUTES

\begin{tabular}{|c|c|c|c|c|c|c|c|}
\hline & $\begin{array}{c}\text { Clay } \\
(\%)\end{array}$ & $\begin{array}{c}\text { Sand } \\
(\%)\end{array}$ & $\begin{array}{c}\text { Gravel } \\
(\%)\end{array}$ & $\mathrm{OMC}_{(\%)}$ & $\begin{array}{c}\mathrm{MDD} \\
\left(\mathbf{k N} / \mathbf{m}^{3}\right)\end{array}$ & $\underset{(\%)}{\text { CBR Un soaked }}$ & $\underset{(\%)}{\text { CBR Soaked }}$ \\
\hline Clay $(\%)$ & 1 & -1 & -1 & 0.99 & -0.98 & -0.92 & -0.92 \\
\hline Sand $(\%)$ & & 1 & 1 & -0.99 & 0.98 & 0.915 & 0.925 \\
\hline Gravel (\%) & & & 1 & -0.99 & 0.98 & 0.915 & 0.925 \\
\hline $\mathrm{OMC}(\%)$ & & & & 1 & -0.99 & -0.88 & -0.893 \\
\hline $\operatorname{MDD}\left(\mathrm{kN} / \mathrm{m}^{3}\right)$ & & & & & 1 & 0.844 & 0.859 \\
\hline CBR Un soaked(\%) & & & & & & 1 & 0.994 \\
\hline CBR Soaked $(\%)$ & & & & & & & 1 \\
\hline
\end{tabular}

TABLE IV Results Of Unsoaked Lab. CBR And Predicted CBR For Optimum Moisture Content

\begin{tabular}{|c|c|c|c|c|}
\hline $\begin{array}{c}\text { Sr. } \\
\text { No. }\end{array}$ & $\begin{array}{c}\text { OMC } \\
\text { (\%) }\end{array}$ & $\begin{array}{c}\text { Lab. CBR- } \\
\text { US (\%) }\end{array}$ & $\begin{array}{c}\text { Predicated } \\
\text { CBR-US (\%) }\end{array}$ & $\begin{array}{c}\text { Residuals } \\
(\%)\end{array}$ \\
\hline 1 & 8.26 & 74.98 & 57.49 & 17.49 \\
\hline 2 & 8.56 & 50.55 & 53.05 & -2.49 \\
\hline 3 & 9.1 & 42.06 & 45.06 & -3.00 \\
\hline 4 & 9.46 & 31.18 & 39.73 & -8.55 \\
\hline 5 & 9.9 & 23.55 & 33.23 & -9.68 \\
\hline 6 & 10.7 & 16.75 & 21.40 & -4.65 \\
\hline 7 & 12 & 13.08 & 2.18 & 10.90 \\
\hline
\end{tabular}

Regression line CBR-(Un soaked) $=-179.64-14.78(\mathrm{OMC})$

coefficients of determination, $R^{2}=0.78$,

\section{OMC(\%) Residual}

Plot
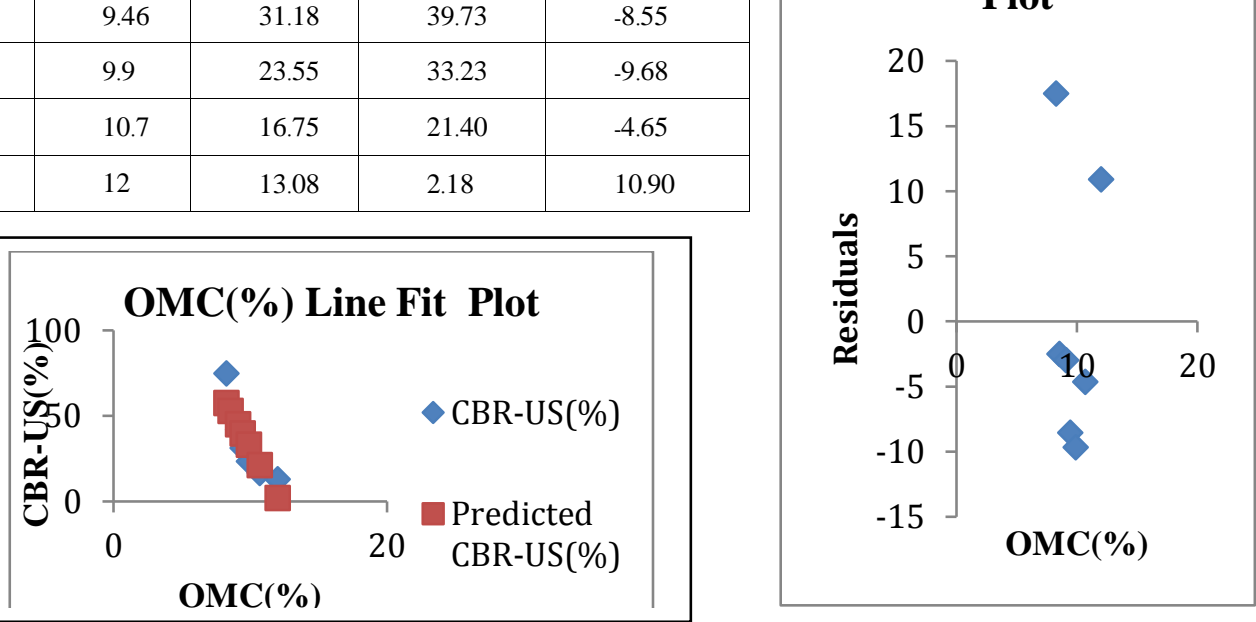

Fig.3 OMC (\%) fit plot

Fig.3 OMC (\%) residua 
TABLE V Results of unsoaked lab. CBR and predicted CBR for maximum dry density

\begin{tabular}{|c|c|c|c|c|}
\hline Sr. No. & $\begin{array}{c}\text { MDD } \\
(\%)\end{array}$ & $\begin{array}{c}\text { Lab. CBR- } \\
\text { US (\%) }\end{array}$ & $\begin{array}{c}\text { Predicated } \\
\text { CBR-US (\%) }\end{array}$ & $\begin{array}{c}\text { Residuals } \\
(\%)\end{array}$ \\
\hline 1 & 2.149 & 74.98 & 54.04 & 20.93 \\
\hline 2 & 2.13 & 50.55 & 50.14 & 0.40 \\
\hline 3 & 2.12 & 42.06 & 48.08 & -6.02 \\
\hline 4 & 2.09 & 31.18 & 41.92 & -10.74 \\
\hline 5 & 2.05 & 23.55 & 33.70 & -10.15 \\
\hline 6 & 1.99 & 16.75 & 21.37 & -4.62 \\
\hline 7 & 1.9 & 13.08 & 2.87 & 10.20 \\
\hline
\end{tabular}

Regression line CBR (US) = 387.58+205.5 (MDD),

coefficients of determination, $\mathrm{R}^{2}=0.71$.

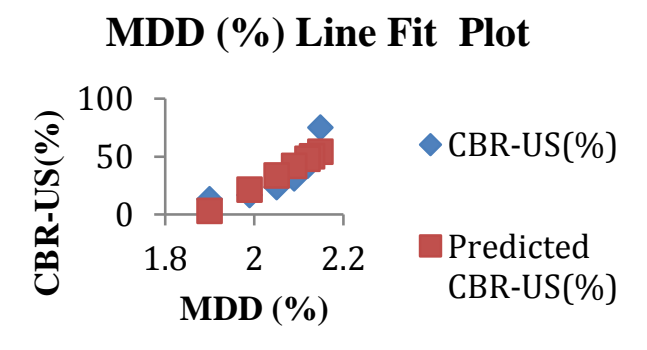

Fig.4 MDD line fit plot

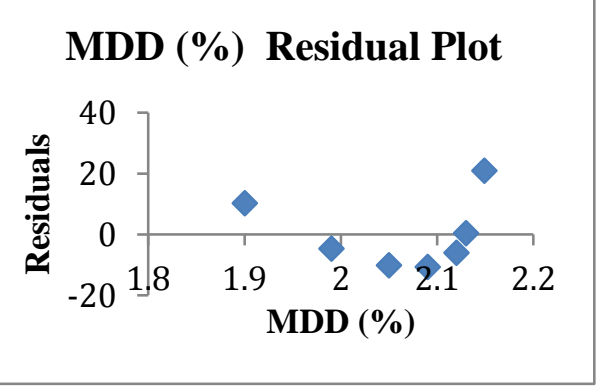

Fig.5 MDD residual plot

TABLE VI
\begin{tabular}{|c|c|c|c|c|}
\hline Sr. No. & $\begin{array}{c}\text { OMC } \\
(\%)\end{array}$ & CBR-S $(\%)$ & $\begin{array}{c}\text { Predicated } \\
\text { CBR-S }(\%)\end{array}$ & $\begin{array}{c}\text { Residuals } \\
(\%)\end{array}$ \\
\hline 1 & 8.26 & 60.5 & 47.93 & 12.57 \\
\hline 2 & 8.56 & 44.13 & 43.95 & 0.17 \\
\hline 3 & 9.1 & 36.85 & 36.79 & 0.05 \\
\hline 4 & 9.46 & 24.2 & 32.03 & -7.82 \\
\hline 5 & 9.9 & 15.6 & 26.20 & -10.59 \\
\hline 6 & 10.7 & 11.28 & 15.60 & -4.31 \\
\hline 7 & 12 & 8.32 & -1.63 & 9.95 \\
\hline
\end{tabular}

MOISTURE CONTENT

Regression line CBR-(S)=157.39 13.25(OMC)

Coefficient of determination $\mathrm{R}^{2}=0.8$.

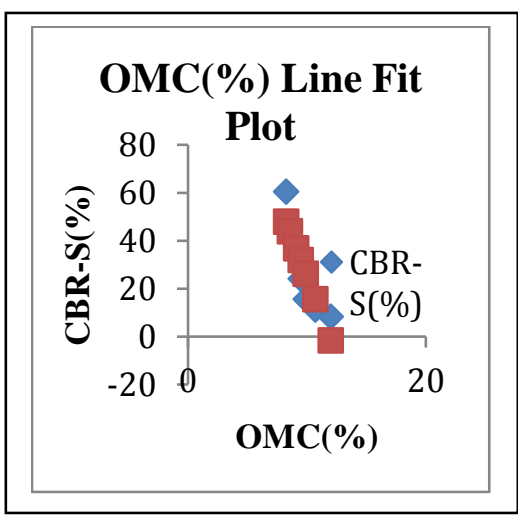


TABLE VII Results of soaked lab. CBR and predicted CBR for maximum dry density

\begin{tabular}{|c|c|c|c|c|}
\hline Sr. No. & $\begin{array}{c}\text { MDD } \\
(\mathrm{g} / \mathrm{cc})\end{array}$ & CBR-S (\%) & $\begin{array}{c}\text { Predicated } \\
\text { CBR-S }(\%)\end{array}$ & $\begin{array}{c}\text { Residuals } \\
(\%)\end{array}$ \\
\hline 1 & 2.14 & 60.5 & 44.95 & 15.55 \\
\hline 2 & 2.13 & 44.13 & 41.43 & 2.70 \\
\hline 3 & 2.12 & 36.85 & 39.57 & -2.72 \\
\hline 4 & 2.09 & 24.2 & 34.01 & -9.81 \\
\hline 5 & 2.05 & 15.6 & 26.60 & -11.00 \\
\hline 6 & 1.99 & 11.28 & 15.49 & -4.21 \\
\hline 7 & 1.9 & 8.32 & -1.18 & 9.50 \\
\hline
\end{tabular}

Regression line $\mathrm{CBRS}=-353.16+$ 185.25(MDD),

Coefficient of determination $\mathrm{R}^{2}=0.74$,

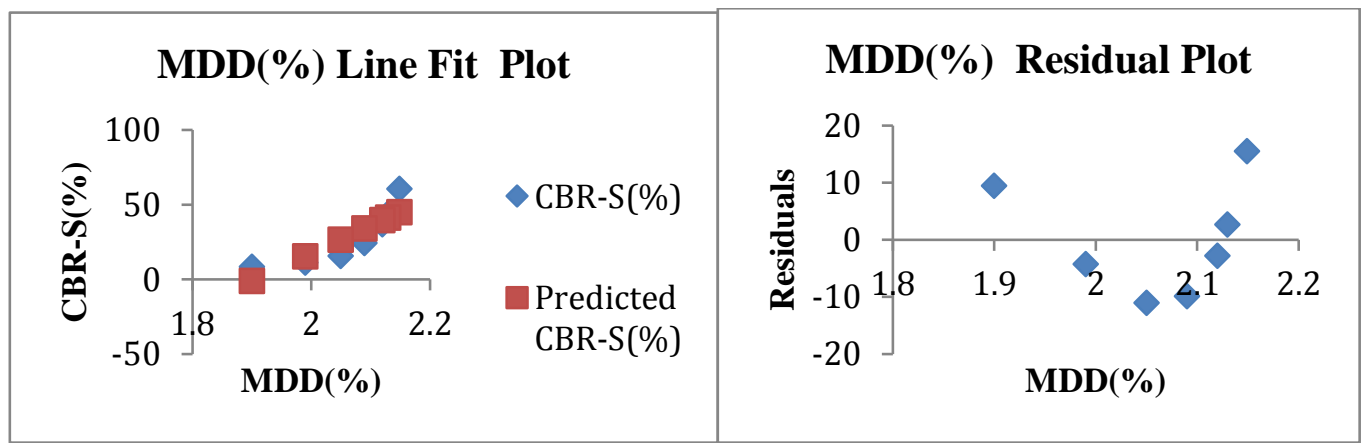

Fig.8 MDD line fit plot for soaked samples

Fig.9 MDD line fit plot for soaked samples

\section{Conclusion}

The compaction effect and water content have remarkable effect on California bearing ratio. These two factors should be strictly controlled in the construction.

With increase in fine particles, the optimum moisture content increases but reduction in maximum dry density is moderate because sand and gravels used are uniformly graded.CBR values are more sensitive at smaller amount of clay percentage. The reduction of CBR values is not linearly related with the fine particle content. The CBR values of un soaked and soaked condition decrease with particle fines improved. This is because when fine particles are added, the hydrate film between fine particles become thin. When CBR test is done, the friction between soil particles are not direct friction by particle surface but friction by hydrate film. The hydrate film plays a role like lubricant and friction decreases eventually.

The points in a residual plot are randomly dispersed around the horizontal axis, which indicates that regression model are appropriate. But for maximum dry density the residual plot is not random and hence shows nonlinear relationship.

It should be noted that, above developed equations are acceptable which are derived on test conditions and prevailing material properties. 


\section{References}

[1] D,J.,Vipulanandan,S.,2011.“Characterization of Field Compacted Soils ( Unsoaked) Using the California Bearing Ratio (CBR) Test" ASCE.pp. 2719-2728.

[2] LIU, Z, ZHANH,. Yongman et al.2009. "Analysis on the factors affecting the CBR value of silt road bed" ASCE.pp.18141819.

[3] H.Suksun., Apichat, S., et al.2013. "Compaction behavior of fine grained soils, lateritic soils and crushed rocks" Soils and Foundations ,The Japanese Geotechnical society,53(1);pp- 166-172.

[4] P.,K,.Sridhran,A, et al. 2014." A study of compaction characteristics of fine grained soil" Proceedings of Indian Geotechnical Conference.pp-6-13.

[5] D.Talukdar,.2014. "A study of correlation between California Bearing Ratio (CBR) value with other properties of soil". International Journal of Emerging Technologyand Advanced Engineering" Vol. 4,pp-550-562.

[6] A. Kumar Sabat "Prediction of California Bearing Ratio of a Soil Stabilized with Lime and Quarry Dust Using Artificial Neural Network" EJGE Vol.18 (2013)

[7] T.K.Roy, Chattopadhyay,B.C.et al "California Bearing Ratio, Evaluation and Estimation: A study on comparisons." Indian Geotechnical Conference-2010.GEOtrendzDecember2010,IIT Bombay.

[8] P.Shau,., Reddy,S.K. "Evalution of sub grade of soil using dynamic cone penetrometer" International Journal Of Earth Sciences \& Engineering ISSN 0974-5904, Vol.04, , PP. 384-388

[9] P. Muley \& P.K. Jain, "Betterment and prediction of CBR of stone dust mixed poor soils" Proceedings of Indian geotechnical conference Dec. 22-24,2013., Roorkee.

[10] Patel,M.A., Patel, H.S., 2012."Laboratory assessment to correlate parameter from physical properties of sub grade" $3^{\text {rd }}$ Nirma University International Conference On Engineering .pp.201-209.

[11] Suneet,.K.,Ubboveja,V.S,.Agrawal,A.,2011 Artificial Neural Network Modeling For Prediction of CBR" Indian Highways, pp.31-38.

[12] Arora,K.R.," Soil Mechanics and Foundation Engineering", $7^{\text {th }}$ edition, Standard Publishers Distributors, New Delhi,2008.

[13] R.Gopal., Rao.,A.,S., "Basic and Applied Soil Mechanics" $2^{\text {nd }}$ edition, New Age International (P) limited, Publishers, New Delhi, 2014

[14] IS : 2720 (Part-4)-1985, Methods of Test for Soils: Grain Size Analysis

[15] IS : 2720 (Part-8)-1983, Methods of Test for Soils: Determination of Water content-Dry density Relation using heavy compaction.

[16] IS : 2720 (Part-16)-1983, Methods of Test for Soils: Laboratory Determination of CBR. 